\title{
MENJADI GURU MAHIR MICROSOFT OFFICE PADA SEKOLAH SMA TAMAN SISWA SUKADAMAI
}

\author{
Havid Syafwan ${ }^{1}$, Nurwati ${ }^{2}$, Andrinata ${ }^{3}$, Ari Dermawan ${ }^{4}$ \\ ${ }^{1,3,4}$ Manajemen Informatika, AMIK ROYAL Kisaran \\ ${ }^{2}$ Teknik Komputer, AMIK ROYAL Kisaran \\ email: havid_syafwan@yahoo.com
}

\begin{abstract}
Community Service Activities is conducted in the form of one day training for teachers in using Microsoft Office software as one way to utilize information technology in delivering learning materials to students especially in SMA Tamansiswa Suka Damai. The target in this activity is the teachers of Tamansiswa Suka Damai High School in District Pulo Bandring Kab. Asahan which amounted to approximately 18 people. This devotional activity is done by lecture method, demonstration, and practice with question and answer. The lecture method is used to explain the introductory concept of the introduction of Microsoft Office software as one of the media in facilitating human work. Demonstration method is used to show a working process that is the stages of recognizing the tools that exist in the Microsoft Office software and know each function, while the practice method to practice the use of the application directly. While the question and answer method to give the participants the opportunity in consultation to overcome obstacles in understanding the material already obtained. The end result of this activity is expected to accelerate and facilitate the teachers in delivering learning materials to the students.
\end{abstract}

Keywords: Microsoft Office software, teachers, students, information technology

\begin{abstract}
Abstrak: Kegiatan Pengabdian Masyarakat ini dilaksanakan dalam bentuk pelatihan sehari bagi guru-guru dalam menggunakan software Microsoft Office sebagai salah satu cara dalam memanfaatkan teknologi informasi dalam menyampaikan materi pembelajaran kepada siswa-siswi khususnya di SMA Tamansiswa Suka Damai. Sasaran dalam kegiatan ini adalah para guru-guru SMA Tamansiswa Suka Damai di Kecamatan Pulo Bandring Kab. Asahan yang berjumlah lebih kurang 18 orang. Kegiatan pengabdian ini dilakukan dengan metode ceramah, demonstrasi, dan latihan yang disertai tanya jawab. Metode ceramah digunakan untuk menjelaskan konsep pengantar dari pengenalan software Microsoft Office sebagai salah satu media dalam mempermudah pekerjaan manusia. Metode demonstrasi dipakai untuk menunjukkan suatu proses kerja yaitu tahaptahap mengenalan tool-tool yang ada pada software Microsoft Office dan mengetahui masing-masing fungsinya, sedangkan metode latihan untuk mempraktikkan langsung penggunaan aplikasi tersebut. Sementara metode tanya jawab untuk memberi kesempatan para peserta dalam berkonsultasi untuk mengatasi kendala dalam memahami materi yang sudah didapat. Hasil akhir dari kegiatan ini diharapkan dapat mempercepat dan mempermudah para guru dalam meyampaikan materi pembelajaran kepada siswasiswinya.
\end{abstract}

Kata kunci: Software Microsoft Office, Guru, Siswa-siswi, teknologi informasi 
Vol. 1, No. 2, Jul 2018, hlm. $75-80$

ISSN 2614-7912 (cetak)

ISSN 2622-3813 (online)

Available online at http://jurnal.stmikroyal.ac.id/index.php/jurdimas

\section{PENDAHULUAN}

Saat ini kemajuan teknologi dan ilmu pengetahuan sangat pesat. Kemajuan yang sangat pesat terutama dalam bidang komputer. Kemampuan dalam menggunakan komputer sangat diperlukan dalam bidang pekerjaan kehidupan seharihari. Komputer ini telah dikenal mulai dari tingkat SMP (sederajat), SMA (sederajat) atau bahkan kalangan anakanak usia dini. Di kalangan pengajar (guru) khususnya, kebutuhan akan kemampuan menggunakan komputer sangat terasa. Terutama dalam penyelesaian pekerjaan dan menambah pengetahuan dalam bidang komputer.

Kemampuan tersebut tidak hanya mengenal komputer secara global, melainkan juga seorang guru dituntut mampu mengoperasikan komputer sebagai salah satu cara untuk menyelesaikan pekerjaan yang akan disajikan kepada siswa serta sebagai upaya untuk peningkatan kompetensi pengetahuan dalam bidang komputer

Dalam buku karangan Sharoon E Smaldino yang berjudul Instructional Technology and Media For Learning, menyebutkan bahwa pada abad 21 guru harus mempunyai beberapa kemahiran untuk menyiapkan peserta didik yang siap bersaing. Diantara kemahiran tersebut adalah Computer literacy. Computer literacy adalah kemampuan guru dalam memilih dan menggunakan teknologi untuk meningkatkan kesempatan belajar siswa termasuk bagaimana cara menggunakan sistem operasi dan bagaimana menemukan solusi dari masalah pada hardware dan software.

Selain itu sebenarnya banyak guru yang masih memiliki pengetahuan minim sekali tentang program-program yang ada dalam komputer salah satunya Microsoft Office. yaitu diantaranya program Microsoft word, Microsoft Excel, Microsoft PowerPoint, Padahal kemampuan ini sangat diperlukan dalam usaha penyelesaian tugas-tugas yang diberikan oleh lembaga sekolah nantinya. Oleh karena itu, Perguruan Tinggi AMIK Royal Kisaran dengan dasar ini tertarik untuk mengadakan pengabdian di Kecamatan Pulo Bandring bagi para guruguru dengan kegiatan pengolahan data berbasis SPSS yang dapat berguna bagi guru-guru SMA Tamansiswa Suka Damai terutama dalam hal kegiatan belajar mengajar sehingga dapat terbentuk pelajar-pelajar yang berkualitas yang dapat mengaplikasikan komputer khususnya Program Aplikasi Microsoft Office.

\section{METODE}

Kegiatan pengabdian ini di lakukan dengan metode ceramah, demonstrasi, dan latihan yang disertai tanya jawab. Metode ceramah digunakan untuk menjelaskan konsep pengantar dari pengenalan software Microsoft Office sebagai salah satu media dalam mempermudah pekerjaan manusia. Metode demonstrasi dipakai untuk menunjukkan suatu proses kerja yaitu tahap-tahap mengenalan tool-tool yang ada pada software Microsoft Office dan mengetahui masing-masing fungsinya, sedangkan metode latihan untuk mempraktikkan langsung penggunaan aplikasi tersebut. Sementara metode tanya jawab untuk memberi kesempatan para peserta dalam berkonsultasi untuk mengatasi kendala dalam memahami materi yang sudah didapat.

\section{PEMBAHASAN}

Definisi dan Perkembangan Microsoft Office Microsoft Office adalah paket software buatan Microsoft Coorporation yang dirancang untuk memudahkan tugas perkantoran. Dengan Microsoft Office kita bisa mengetik proposal, surat, laporan keuangan, 
Vol. 1, No. 2, Jul 2018, hlm. $75-80$

ISSN 2614-7912 (cetak)

ISSN 2622-3813 (online)

Available online at http://jurnal.stmikroyal.ac.id/index.php/jurdimas

presentasi, database karyawan, membuat logo, dan lain-lain.

Beberapa aplikasi di dalam Microsoft Office yang terkenal adalah Excel, Word, dan PowerPoint. Microsoft Office untuk Windows dimulai pada bulan Oktober 1990 sebagai paket dari tiga aplikasi yang dirancang untuk Microsoft Windows 3.0: Microsoft Word untuk Windows 1.1, Microsoft Excel untuk Windows 2.0, dan Microsoft PowerPoint untuk Windows 2.0.

Lalu setelah populer, pada tahun 1995 Microsoft kembali meluncurkan aplikasi kantoran ini dengan versi 1995 bersama dengan OS Windows 95-nya. Pada sistem operasi ini Microsoft merombak total Windows versi 3.1 dan Windows 3.11 for Workgroup, perubahan yang cukup signifikan dalam sejarah sistem operais PC saat itu. Sejalan dengan pekembangan sistem operasi Microsoft Windows, Microsoft Office sendiri terus berkembang dan semakin mapan dan terus digandrungi serta digunakan oleh sebagian besar masyarakat komputer di dunia, termasuk di Indonesia. Sampai pada tahun 2000-an Microsoft sudah meluncurkan beberapa versi Microsoft Office dan sampai saat ini masih tetap digunakan sebagai andalan aplikasi perkantoran modern. Beberapa versi dari Microsoft Office yang masih banyak digunakan saat ini antara lain Microsoft Office 2000, Microsoft Office XP (2002), Microsoft Office 2003, Microsoft Office 2007 dan yang terakhir sampai sekarang adalah Microsoft Office 2010.

Karena keterbatasan waktu, maka tim PKM hanya membatasi materi kegiatan tentang Microsoft word. Berikut tampilan Microsoft word 2007 Beserta fungsi dari toolbarnya.

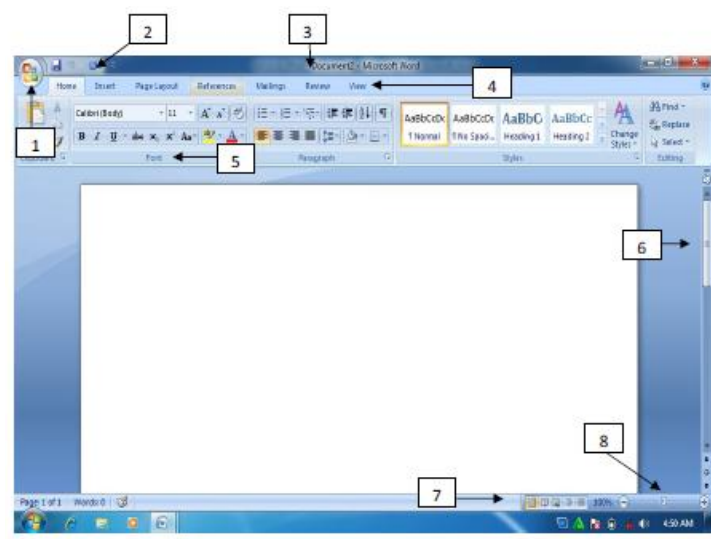

Gambar 1. Tampilan halaman utama MS Word 2007

Keterangan Gambar:

1. Microsoft office button Tombol ini berisi menu-menu sebagai berikut: new, open, save, save as, print, dll.

2. Quick acces toolbar.

Merupakan kumpulan tombol yang bisa ditambahkan atau dikurangi sesuai dengan keinginan pengguna. Pada kumpulan tombol ini bias dimasukkan tombol open, new,save, preview, dan lain-lain.

3. Title bar

Menunjukkan judul document yang dibuat. Apabila document tersebut baru pertama kali dibuat, maka secara otomatis bernama document 1 .

4. Tab ribbon

Merupakan deretan menu utama yang digunakan untuk mengakses beberapa fungsi yang terdiri dari beberapa grup. Masing-masing grup dikelompokkan sesuai fungsinya masing-masing.

5. Group

Menunjukkan kelompok perintah yang memiliki kesamaan fungsi. Perintahperintah tersebut ditandai dengan gambar (icon).

6. Scroll

Scroll digunakan untuk menggulung lembar kerja ke atas atau ke bawah

7. View mode

Berfungsi untuk mengatur mode tampilan yang terdiri dari printout, full screen reading, web layout, outline serta draft. 
Vol. 1, No. 2, Jul 2018, hlm. $75-80$

Available online at http://jurnal.stmikroyal.ac.id/index.php/jurdimas

\section{Zoom slider}

Berfungsi untuk memperbesar atau memperkecil tampilan lembar kerja.

Contoh Cara Membuat Bullet and Numbering

Bullet dan numbering bermanfaat dalam menunjukkan beberapa opsi atau pilihan sebagai keterangan pelengkap dalam paragraph jika teks pada paragraph tersebut akan diberikan beberapa point pembahasan. Jika opsi atau keterangan ditampilkan bukan dalam bentuk urutan langkah, biasanya digunakan bullet. Cara membuatnya adalah sebagai berikut:

1) Pilih teks yang akan diberi bullet

2) Klik Bullet pada ribbon Home

3) Klik bullet yang diinginkan.

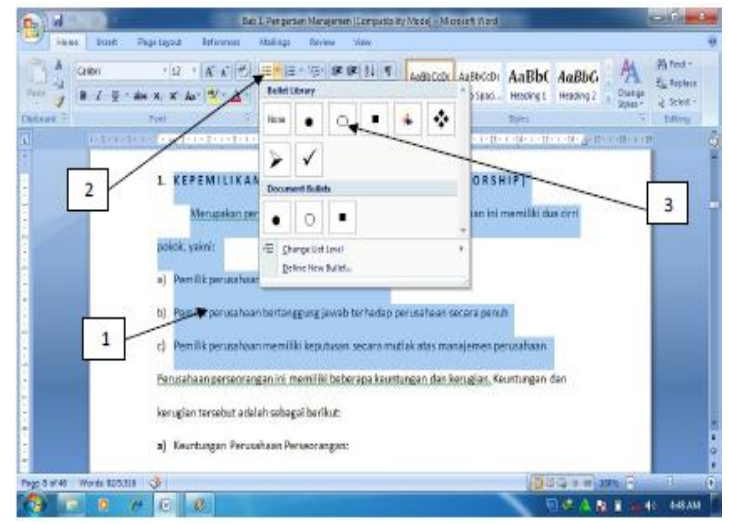

Gambar 2. Tampilan pembuatan bullet

Bila opsi atau keterangan secara detil ingin ditampilkan dalam bentuk urutan langkah atau urutan kejadian, biasanya digunakan Numbering atau penomoran.

Numbering bisa berupa angka maupun huruf. Langkah-langkah pemberian numbering adalah hampir sama dengan pemberian bullet, pada ribbon home klik Number.

Contoh Cara Membuat Rumus

Fasilitas Equation dalam MS Word 2007 memberikan kemudahan bagi penggunaya bila ingin membuat rumus matematika, statistik maupun rumus-rumus ilmiah lainnya. Langkah-langkah membuat rumus mtematika tersebut adalah sebagai berikut:

1) Klik ribbon Insert

2) Klik Equation, pilih New Equation

3) Klik rumus yang akan dipilih

4) Tuliskan rumus pada bidang penulisan rumus

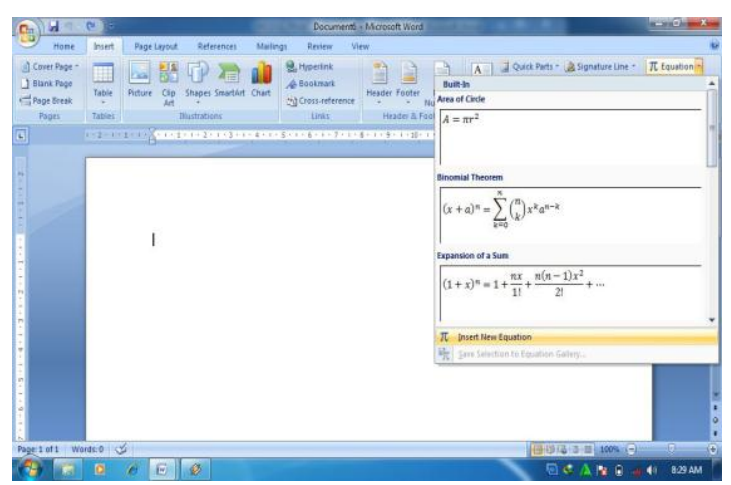

Gambar 3. Tampilan pembuatan equation

Contoh Cara Membuat tabel

Table seringkali disisipkan dalam penulisan artikel ilmiah, buku teks ataupun artikel lainnya sebagai alat bantu dalam memberikan informasi yang rinci tetapi ringkas penyajiannya. Cara pembuatan tabel adalah sebagai berikut:

1) Klik insert pada ribbon home.

2) Klik table, kemudian Klik insert table

3) Tentukan jumlah baris dan kolom yang diinginkan

4) Klik Ok

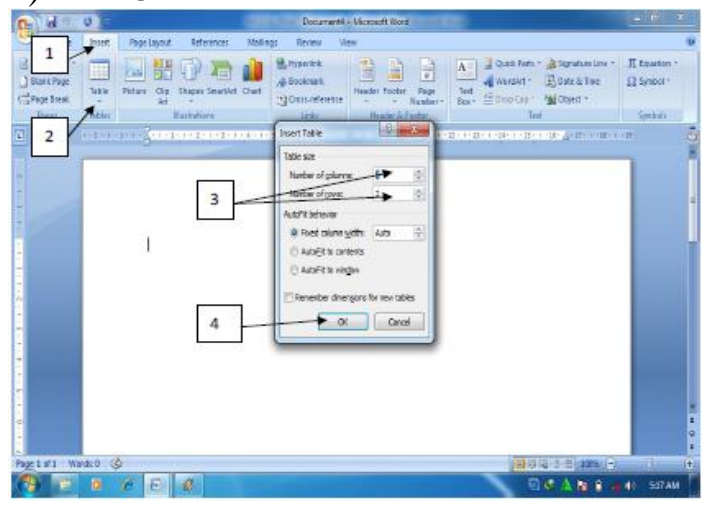

Gambar 4. Tampilan pembuatan tabel

Untuk membuat tabel secara cepat, bisa digunakan fasilitas Quict Table dalam MS Word, fasilitas ini memungkinkan pengguna membuat tabel secara cepat 


\section{Jurdimas (Jurnal Pengabdian Kepada Masyarakat) Royal}

Vol. 1, No. 2, Jul 2018, hlm. 75 - 80

ISSN 2614-7912 (cetak)

ISSN 2622-3813 (online)

Available online at http://jurnal.stmikroyal.ac.id/index.php/jurdimas

dengan format tabel yang sudah disedian oleh MS Word. Caranya adalah sebagai berikut:

1) Klik insert

2) Klik Table

3) Klik Quick Table

4) Pilih jenis tabel yang diiginkan.

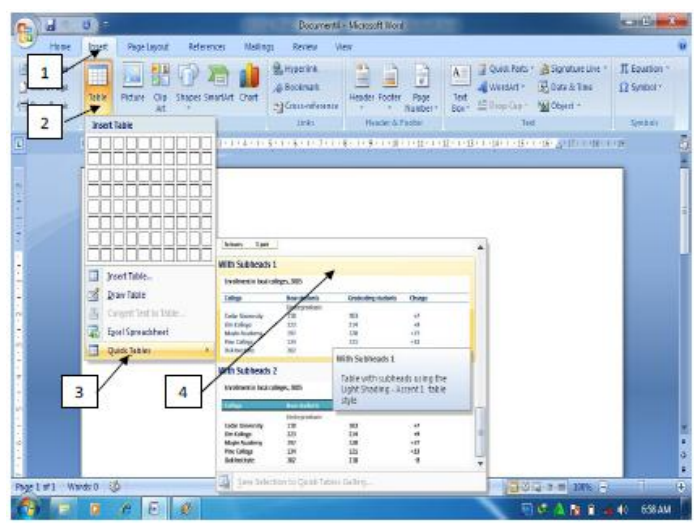

Gambar 5. Tampilan pembuatan tabel

Berikut ini dokumentasi kegiatan pengabdian kepada masyarakat dengan tema menjadi guru mahir Microsoft Office di SMA Tamansiswa Suka Damai di Kecamatan Pulo Bandring Kab. Asahan:

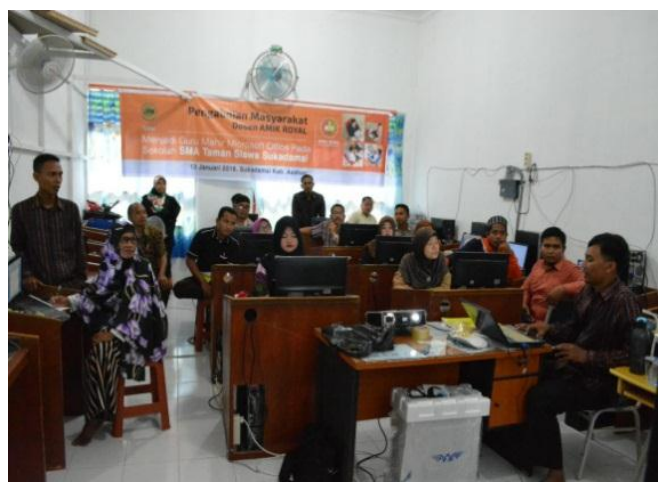

Gambar 6. Penyampaian materi oleh narasumber

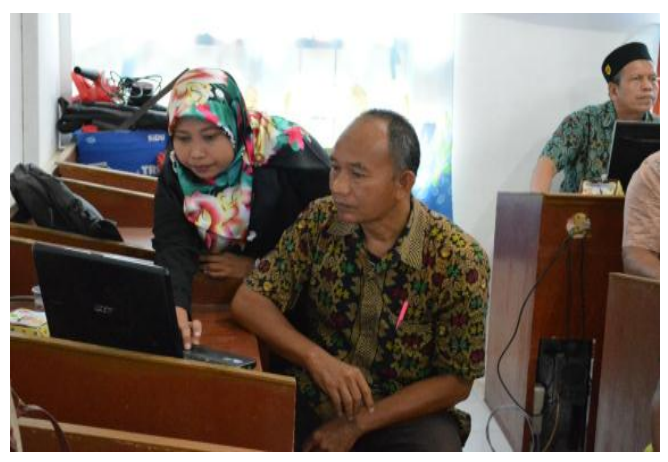

Gambar 7. Penyampaian materi oleh narasumber

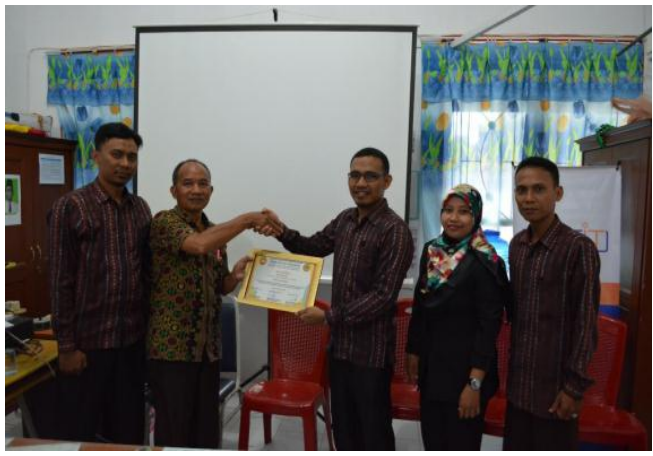

Gambar 8. Penyerahan Cinderamata kepada Bapak Kepala Sekolah SMA Tamansiswa Suka Damai oleh Tim PKM

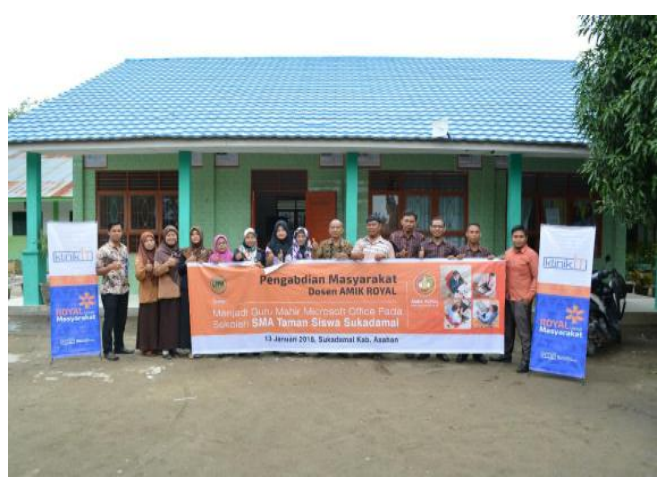

Gambar 9. Foto bersama peserta kegiatan PKM

\section{SIMPULAN}

Dari hasil evaluasi serta temuantemuan yang diperoleh selama pelaksanaan kegiatan Pengabdian Masyarakat ini, dapat dsimpulkan bahwa program Pengabdian Masyarakat ini telah mampu memberikan manfaat yang sangat besar dan tepat sasaran bagi para guru guru SMA Tamansiswa Suka Damai. Bentuk pelatihan seperti ini merupakan bentuk yang sangat efektif untuk memberikan penyegaran dan tambahan wawasan serta pengetahuan baru di bidang teknologi informasi di luar proses pembelajaran yang diterima di SMA Tamansiswa Suka Damai.

Untuk Pengembangan selanjutnya kami menyarankan hendaknya program- 
program pengabdian masyarakat seperti ini bisa dilaksanakan secara reguler dan berkala, melihat tingkat kebutuhan yang sangat tinggi akan pengenalan aplikasiaplikasi komputer yang baru, dengan jangka waktu yang relatif singkat dalam mengikuti perkembangan teknologi secara global.

\section{UCAPAN TERIMA KASIH}

Kegiatan ini merupakan hasil dari kerjasama antara sivitas akademika AMIK Royal dengan Sekolah SMA Tamansiswa Suka Damai Kecamatan Pulo Bandring Kabupaten Asahan serta

\section{DAFTAR PUSTAKA}

LPPM. (2017). Format Penulisan Jurdimas. Kisaran : STMIK Royal.

Mukhlasin, Hafid (2013). Kupas Tuntas Microsoft Word 2010. IlmuKomputer.com.

Kurniawan, Bobi. (2017). Program IPTEK bagi Inovasi dan bantuan materi, tenaga, dan fikiran dari berbagai pihak. Untuk itu, Tim pengabdian kepada masyarakat AMIK Royal Kisaran mengucapan terima kasih yang sebesar-besarnya kepada:

1. Bapak Anda Putra Lubis, SE., MMA, Ketua Yayasan Royal Teladan Asahan, sebagai penyandang dana,

2. Bapak Pardiman, S.Pd, kepala sekolah SMA Tamansiswa Suka Damai Kab. Asahan, sebagai mitra kegiatan pengabdian kepada masyarakat,

3. Tim pengabdian kepada masyarakat yang telah bekerjasama dengan baik, sehingga kegiatan dapat berjalan lancar dan sukses.

kreativitas Kampus IT Training and Service Centre (ITSC) UNIKOM (JPKM, Vol. 3 No. 1.Hal 18-25).

Utama, Agung. (2010). Modul Praktikum Aplikasi Komputer. Yogyakarta : Jurusan Manajemen, Fakultas Ilmu Sosial dan Ekonomi UNY. 